\title{
Traditional Agroforestry Systems and Food Supply under the Food Sovereignty Approach
}

\author{
Mariana Y. Hernández ${ }^{1}$, Pedro A. Macario ${ }^{1 *}$, and Jorge O. López-Martínez ${ }^{2}$ \\ ${ }^{1}$ Department of Agriculture, Society and Environment, El Colegio de la Frontera Sur (ECOSUR), Chetumal, Quintana Roo, \\ Mexico. ${ }^{2}$ CONACYT- ECOSUR. Chetumal, Quintana Roo, Mexico. \\ *pmacario@ecosur.mx
}

\begin{abstract}
Intensive production systems have damaged many natural ecosystems and have altered their capacity to provide ecosystem services such as climate regulation, soil fertility, and vector-borne disease control. Therefore, these agroecosystems are unsustainable and poorly resilient. However, traditional agroforestry systems (TAS) contribute to the conservation of biodiversity and to the provision of inputs for the maintenance of local populations. The objective of this study was to evaluate the contribution of the TAS in the food supply under the food sovereignty (FSv) approach in three different ethnic groups. The study was conducted in three communities of different origin in the State of Campeche, one Maya Tseltal-Chol, the other Mestizo and the third Yucatec Mayan. The theoretical-methodological framework of this research was based on agroecology. Ethnographic methods and participatory research activities were carried out to describe and analyze the factors that strengthen FSv using five FSv indicators. Our results present a description and analysis of resource access, current production models, patterns of consumption and food security, commercialization and participation in decision-making of these communities. Traditional agroecological management practices are still preserved and native species are still being cultivated. Farmers obtain about 55\% of their food from TAS. The consumption of food is influenced by the culture, the purchasing power linked to economic activities and government support. TAS have played a strategic role for the survival of families but to ensure their contribution to FSv, it is necessary to articulate the actions of the sectors that share the same objective and encourage the active participation of communities in agricultural policies.
\end{abstract}

Received March 20, 2017

OPENӘACCESS

Accepted July 31, 2017

DOI 10.14237/ebl.8.1.2017.941

Keywords Traditional agroecosystems, Agroecology, Food consumption, Food supply, Participatory research

Copyright (c) 2017 by the author(s); licensee Society of Ethnobiology. This is an open-access article distributed under the terms of the Creative Commons Attribution-NonCommercial 4.0 International Public License (https://creativecommons.org/licenses/by-nc/4.0), which permits non-commercial use, distribution, and reproduction in any medium, provided the original author and source are credited.

\section{Introduction}

Intensive production systems, both crop and livestock-oriented, have disrupted and altered many natural ecosystems and traditional agroecosystems, where biodiversity has been replaced by monocultures designed for maximum short-term production (Altieri and Nicholls 2013; Balvanera and Cotler 2009; Senanayake 2003). These highly simplified ecosystems are unstable, unsustainable, and poorly resilient since they use high amounts of external inputs (Altieri and Nicholls 2013; Senanayake 2003). Approximately $80 \%$ of the 1.5 billion hectares of global arable land are devoted to monocultures (Nicholls et al. 2015). In Mexico, 70\% of the 20.8 million hectares are dedicated to industrial agriculture (INEGI 2012).
Under this view, initiatives that apply and combine agroecology with indigenous knowledge systems have emerged (Altieri 2009b). These initiatives have demonstrated that it is possible to improve food security while conserving natural resources and agrobiodiversity (Altieri 2009b; Pretty et al. 2003).

Food sovereignty (FSv) is a concept developed by the international peasants' movement at the World Food Summit 1996 and states that in terms of food, every community has the right to define its own agricultural policies in order to achieve sustainable development and self-sufficiency goals (Vía Campesina 1996). FSv is based on locally produced species grown in diversified systems to obtain safe 
and nutritious food (Cuéllar and Sevilla 2009; Rosset and Martínez 2004). It also considers farmers as guardians of biodiversity, managers of natural resources and custodians of traditional knowledge (Rosset and Martínez 2004).

However, to successfully implement a FSv proposal, tools for analysis, communication and evaluation are needed (Ortega-Cerda and Rivera-Ferre 2010). These authors have categorized and structured five indicators: (i) Access to resources: Individual and community processes of access and control over resources in a sustainable way; (ii) Production models: Diversified local family production through traditional models of sustainable agricultural production; (iii) Safety and food consumption: The right to the consumption of healthy, nutritious and culturally appropriate food from local producers and produced through agroecological techniques; (iv) Transformation and commercialization: Peasants right to sell their products to supply the local population; (v) Agricultural policies: Peasants have the right to know, participate and influence local public policies related to FSv.

On the other hand, agroecology is defined as: "The application of ecological concepts and principles to the design and management of sustainable agroecosystems" (Altieri 2009a:26; Gliessman 2007:18). This science is directly linked to the consolidation and defense of the proposals associated with FSv (Cuéllar and Sevilla 2009).

Agroecosystems under agroecological management can be reservoirs of biodiversity (Perfecto et al. 2009), they contribute by reducing the pressure of deforestation of new areas for agriculture (Moreno-Calles et al. 2013) and they represent a sustainable alternative to the adaptation and mitigation of climate change (Altieri and Nicholls 2013; Casanova-Lugo et al. 2011). In particular, agroforestry systems keep groups of trees and crop species interacting in multistrata systems (Nair 1993; Sánchez 1995; Wojtkowski 2002). The main function is to diversify production to obtain greater environmental, social and economic benefits, following the principle of sustainability (Sodhi and Ehrlich 2010). Agroforestry can benefit biodiversity conservation in three ways: the provision of habitat for forest species in areas that have suffered significant historical deforestation, the provision of a landscape matrix that permits the connectivity of species that benefits migration and dispersal processes, and through the provision of livelihoods for local communities which may in turn relieve pressure on remaining areas of primary forest (Sodhi and Ehrlich 2010). In addition, agroforestry systems contribute to climate change mitigation through carbon sequestration (Casanova-Lugo et al. 2011; Soto -Pinto et al. 2010; Verchot et al. 2007).

In Mexico, traditional agricultural systems and practices based on empirical knowledge developed by farmers are highly important because of their potential benefits, history, and diversification (Hernández 1985; Moreno-Calles et al. 2014). The slash-and-burn milpa system (with a long period of non-cultivated land) where maize (Zea mays L.), bean (Phaseolus spp.), and squash (Cucurbita Spp.) are cultivated with many other crops, and the various types of home gardens: solar, calmil, ekuaro and traspatio (Hernández 1985; MorenoCalles et al. 2014) are among the most significant practices of traditional agroforestry.

This research regarding traditional agroforestry systems (TAS) and FSv was conducted in three communities surrounding the Calakmul Biosphere Reserve (CBR). Moreover, the Reserve faces the great challenge of reaching a balance between the conservation of its biological diversity and the survival of the human communities that inhabit it (Bohn et al. 2014).

Based on the information above, we hypothesized that TAS are a specific type of ecological agriculture and represent an important source of food to meet dietary needs of local populations. The present study aims to answer: What is the role of TAS in the food supply under the food sovereignty approach? To achieve that, we worked towards two specific objectives: 1) Describe and analyze the access to resources, models of production, the marketing mechanism and some of the agricultural policies implemented in our study area; and 2) Determine per household the percentage of food per household that comes from TAS.

\section{Methodology}

Study Area

This research was carried out in three communities that are part of the Calakmul Biosphere Reserve (CBR) in Campeche, Mexico (Figure 1). Unión 20 de Junio (Mancolona) located to $43 \mathrm{~km}$ to the north of Xpujil, the municipality, 20 de Noviembre located $15.5 \mathrm{~km}$ to the southwest $\left(18^{\circ} 27^{\prime} 06^{\prime \prime} \mathrm{N}\right.$ and $89^{\circ} 18^{\prime}$ 

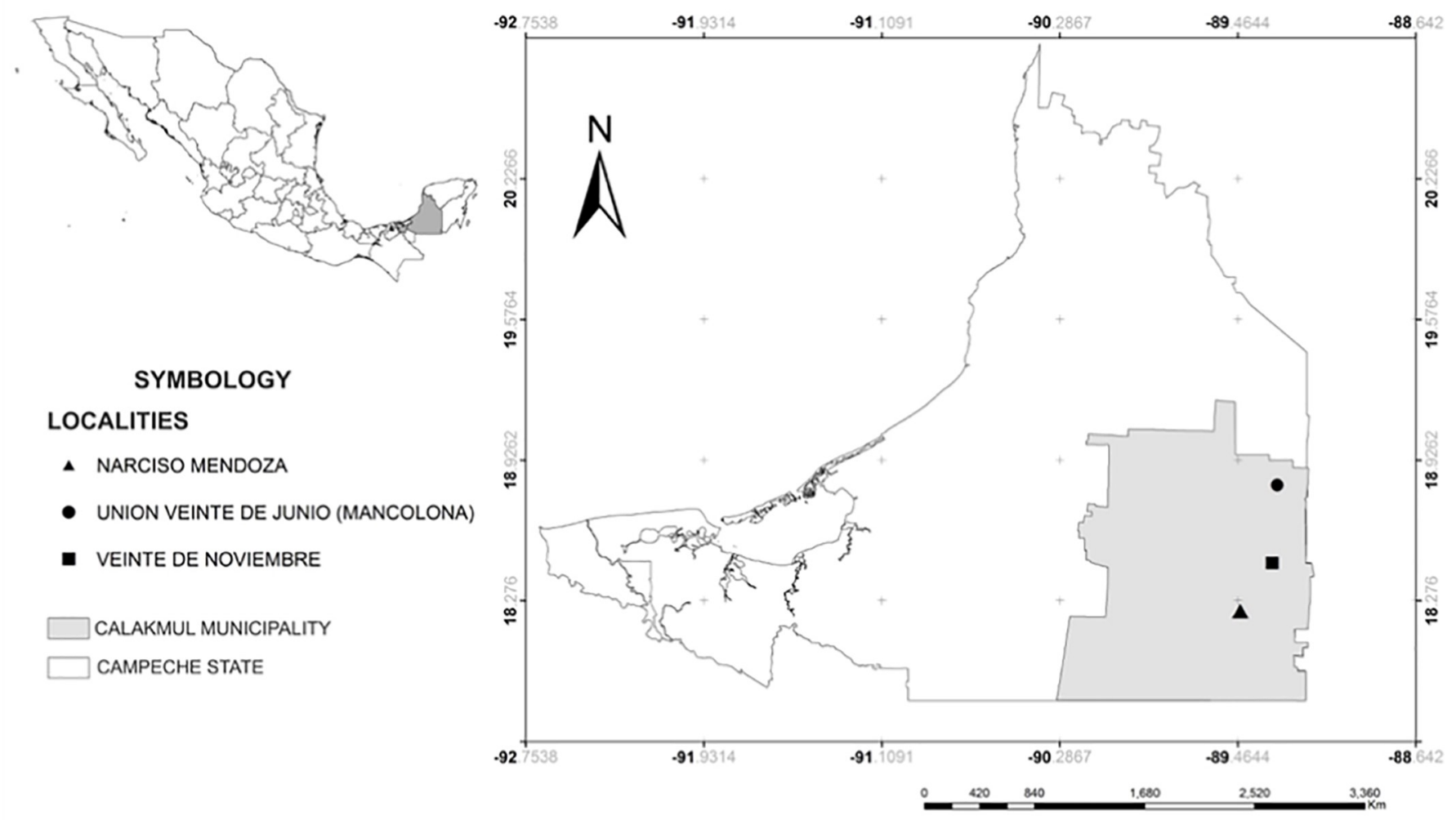

Figure 1 Study area location.

25" W) and Narciso Mendoza located $33 \mathrm{~km}$ to the south (18 ${ }^{\circ} 13^{\prime} 50^{\prime \prime} \mathrm{N}$ and $\left.89^{\circ} 27^{\prime} 12^{\prime \prime} \mathrm{W}\right)$.

This region's climate is warm sub-humid Ax '(w1) with an average annual temperature of $24.9^{\circ} \mathrm{C}$. Mean annual rainfall varies from June to November, averaging 1,000-1,500 $\mathrm{mm}$ per year. The dry season is from December to April, with over $50 \mathrm{~mm}$ during January, which allows agricultural production in autumn and winter (Pool et al. 2000; VillalobosZapata and Mendoza 2010).

The phreatic level is between 60 to $300 \mathrm{~m}$ above sea level with high gypsum content, so the water is not suitable for drinking or irrigation. It has karst landscapes with high rates of permeability, causing water to drain intermittently (Municipio de Calakmul and Proyecto Prosureste GPZ-CONANP 2015). Calakmul is in the Intertropical Convergence Zone (ITCZ), which has periodic droughts and hurricanes, to which the peasants must adapt (Vallejo et al. 2011).

The most representative soils in the area are rendzinas, gleysols, vertisols and lithosols (INECOL 1999; Pool et al. 2000). Calakmul contains the most extensive forest area of the Mexican tropic, whose climatic and edaphic characteristics have the peculiarity of forming a mixture of forest landscapes: mainly medium semi-evergreen forest, sub deciduous forest, low forest and savannah floodplains (Martínez and Galindo-Leal 2002; Noriega-Trejo and Arteaga 2010; Pool et al. 2000).

Calakmul is characterized by a constant fluctuation in the occupation of the land. The community is composed of settlers from 23 states of the country with a strong Indigenous component (Ellis and Porter 2007; Gurri et al. 2002). Migration has contributed to the high cultural diversity in the region, and it has also created a vegetation mosaic with different types of land use, intensities, and types of production (Bovin et al. 2000; Municipio de Calakmul and Proyecto Prosureste (GPZ-CONANP) 2015). Nevertheless, these communities are in a region with poor soils and highly unstable rainfall, which leads to a low agricultural production (Ellis and Porter 2007).

A subsistence-oriented peasant economy predominates throughout the study area, but they are 
increasingly integrated into a market economy. The main economic activities are agriculture and livestock production. Animal husbandry is carried out in homegardens $(91 \%)$ and the rest in pasture areas (Gurri et al. 2002; Municipio de Calakmul and Proyecto Prosureste (GPZ-CONANP) 2015). There are also important groups that produce honey, allspice, chewing gum, resin, and chili. The total land area used for growing maize is more than 10,000 hectares with a production dedicated to selfconsumption and with yields of 0.8 ton/ha (Municipio de Calakmul and Proyecto Prosureste (GPZ-CONANP) 2015). Maize, chibua squash, chili, and beans are cultivated in the milpa (Gurri et al. 2002).

The community Unión 20 de Junio (Mancolona) has a total population of 449 inhabitants, $87 \%$ belong to an indigenous group. On 20 de Noviembre there are 218 inhabitants and 39\% Indigenous people. Finally, Narciso Mendoza has a population of 364 inhabitants and only 3\% speak some Indigenous language (INEGI 2010).

\section{Sampling Design}

This study was conducted in three communities that represent three different cultural backgrounds: Tseltal -Chol Mayan (Unión 20 de Junio), Yucatec Mayan (20 de Noviembre) and Mestizo (Narciso Mendoza). Altogether nine families, three in each village, were chosen based on the ethnic origin and were identified for certain shared characteristics, namely: migrants, pluriactive families, and certain agricultural management practices. Both communities and families were chosen using local knowledge and guidance from key actors. The sampling design was stratified to observe the differences in their food consumption and production.

\section{Data Collection}

The theoretical-methodological framework of this research was based on agroecology (Altieri 2009a). Ethnographic methods for the identification and analysis of social problems regarding $\mathrm{FS} v$ of the communities were used (Hernández 1985). Participant observation, semi-structured interviews, a field log, a diagnostic workshop and documentary research were also employed (Chablé-Can et al. 2015; Huntington 2000; Martin et al. 2010).

The study was carried out from January to October 2016 (with a total of three previous visits in the area and six visits to families who decided to participate in the project with informed consent). To obtain data, the five indicators of FSv were taken as a guide (Ortega-Cerda and Rivera-Ferre 2010). Additionally, based on what Bello and Estrada described (2011), six production and human-nature interaction systems were defined for the Calakmul peasants: milpa, home garden (dooryard garden or solar), secondary vegetation (known as acabual), ranch (plot), and the forest (known as monte).

A) Access to Resources. The first indicator considers the access to natural resources as water, land, forests, animals, seeds, infrastructure and basic services (Ortega-Cerda and Rivera-Ferre 2010). The data was collected using a field log, semi-structured interviews of key actors and participant families, field visits to the communities, and documentary research.

B) Production Model. This indicator takes the use of traditional agroecological and sustainable practices into consideration, as well as diversified family production (Ortega-Cerda and Rivera-Ferre 2010). The information was collected using a field log, semistructured interviews, participant observation, and field visits to the agroecosystems.

C) Security and Food Consumption. Origin of food, consumption of food, culturally appropriate food, and temporality of food were considered for this indicator (Ortega-Cerda and Rivera-Ferre 2010). The percentage of food produced in traditional agroecosystems, the forest, and non-local production systems was recorded using and adapting the dietary diversity tool (Hoddinot 2001) in a participatory diagnostic workshop (Chablé-Can et al. 2015). To carry out this activity, families were summoned two days before. Once in the workshop, family members wrote down in a piece of paper each of the foods they consume throughout the year, origin (production or purchase), the frequency with which they consume those food items and the season of the year in which those foods are produced. In terms of frequency, seven categories were made and a numerical value was assigned to each category: occasional (1), seasonal (2), monthly (3), every two weeks (4), weekly (5), three times a week (6), and daily (7). For every food item, a sum of frequencies was made by families and finally by cultural-ethnic group. Regarding the origin of the food, the participants indicated the place of production and/or purchase. Twenty-seven people between nine to 55 years old participated in the workshops. This technique allowed the social actors 
to play an active role in the execution of the research process.

D) Transformation and Commercialization. This indicator includes local marketing, direct selling or with a minimum of intermediaries (Ortega-Cerda and Rivera -Ferre 2010). To collect this data, we used semistructured interviews, participant observation, and some of the information was also derived from the participatory diagnostic workshop.

E) Agricultural Policies. The last indicator considers participation in decision-making and peasant social organization related to food production, consumption, and commercialization (Ortega-Cerda and Rivera-Ferre 2010). This information was collected through semi-structured interviews of key informants and participant families, as well as documentary research.

\section{Data Analysis}

To organize, describe, and interpret the data collected in the field, the information was classified according to the corresponding $\mathrm{FSv}$ indicator using the qualitative method of data analysis described by Miles and Huberman (1994), which consists of three phases: data display, data reduction, and conclusion drawing and verification. This method was enriched with a coding tool (Miles and Huberman 1994; Patton, 2002). The numeric values used to obtain descriptive statistics were analyzed with R Studio Software.

\section{Results}

Indicators of Food Sovereignty

A) Access to Resources. The people from Unión 20 de Junio (La Mancolona) arrived to Campeche in 1978 but in 1989 when the Calakmul Biosphere Reserve (CBR) was established, the community overlapped with the CBR core area. As a consequence, the community moved again to the CBR buffer zone, where nowadays, 60 small co-owners have private lands (Mendez-Lopez et al. 2014). The ejido Narciso Mendoza was founded in 1976 with 51 ejidatarios originating from Tabasco and Veracruz. The ejido extension is 3,979 hectares (Barbosa et al. 2010). The ejido 20 of November was founded in 1970 with Yucatecan Mayas originating from Dzitbalché, Campeche. They are 100 ejidatarios and the ejido extension is 36,800 hectares (Barbosa et al. 2010).

Access to water is limited, especially in times of drought. Agriculture in the three communities is rainfed. With respect to water consumption for domestic use (Table 1), most households obtain it from rainwater harvesting systems, either in the community or through water tanks at their homes. The only community that has water wells in their homes for the extraction of the resource is 20 de Noviembre. Families reported that during drought season they occasionally use domestic water to water some plants grown in the home garden.

Families conserve and grow their own seedssome have even brought them from their places of

Table 1 Food Sovereignty Indicator. Access to resources: natural resources, infrastructure, and basic services.

\begin{tabular}{|c|c|c|c|c|}
\hline \multirow[b]{2}{*}{$\begin{array}{l}\text { Community- In- } \\
\text { digenous Group }\end{array}$} & \multicolumn{4}{|c|}{ Resources } \\
\hline & Water & $\begin{array}{l}\text { Land/ } \\
\text { Forest }\end{array}$ & Seeds & Infrastructure and basic services \\
\hline $\begin{array}{l}\text { Unión } 20 \text { de Jun- } \\
\text { io (Tseltal-Chol } \\
\text { Mayan) }\end{array}$ & $\begin{array}{l}\text { Community rain- } \\
\text { water harvesting } \\
\text { system (waterhole) }\end{array}$ & Private & $\begin{array}{l}\text { Conserve and cultivate } \\
\text { their own seeds. Re- } \\
\text { ceive maize seeds from } \\
\text { a governmental pro- } \\
\text { gram. }\end{array}$ & $\begin{array}{l}\text { Population with access to health service } \\
94 \% \text { and with schooling } 93 \% \text {. Homes with } \\
\text { electricity: } 91 \% \text {. Connected to the munici- } \\
\text { pality by highway. }\end{array}$ \\
\hline $\begin{array}{l}\text { Narciso Mendoza } \\
\text { (Mestizo) }\end{array}$ & $\begin{array}{l}\text { Piped water and } \\
\text { rainwater har- } \\
\text { vesting per home } \\
\text { and community }\end{array}$ & Ejidal & & $\begin{array}{l}\text { Population with access to health service } \\
59 \% \text { and with schooling } 90 \% \text {. Homes with } \\
\text { electricity: } 93 \% \text { Connected to the munici- } \\
\text { pality by highway. }\end{array}$ \\
\hline $\begin{array}{l}20 \text { de Noviembre } \\
\text { (Yucatec Mayan) }\end{array}$ & $\begin{array}{l}\text { Water well at } \\
\text { home }\end{array}$ & Ejidal & $*$ & $\begin{array}{l}\text { Population with access to health service } \\
58 \% \text { and with schooling } 94 \% \text {. Homes with } \\
\text { electricity: } 96 \% \text { Connected to the munici- } \\
\text { pality by highway. }\end{array}$ \\
\hline
\end{tabular}

Source: Own elaboration based on the information obtained from the interviews and INEGI (2010).

* Same as above. 
origin. However, through the government machining program they are given improved maize seed.

According to the social, economic and demographic indicators of the National Population Council (CONAPO), the three communities have a high rate of marginalization (CONAPO 2010).

B) Production Model. The production model in the three communities follows a similar pattern of management with a considerable gender distribution of work. Men usually work at the milpa, the ranch, or they go to the monte (mountain) looking for wood or hunting. Women oversee home garden management, since their domestic activities require more time at home.

Within the milpa system, people still cultivate varieties of squash (Cucurbita pepo), beans (Phaseolus vulgaris), chihua (Cucurbita argyrosperma), and xpelon (Vigna unguiculata). However, improved maize seeds (Zea mays) have been incorporated into this traditional system. Another way of making milpa is through agroforestry systems, since some fruit and timber species have been established in combination with annual crops. When cultivating and maintaining traditional milpa, no fossil energy source is used since the family's labor sustains the system.

Regarding home gardens, which are also known as solares, it was observed that it is also the family work that supports this system. In general, women are responsible for the management of home gardens, which includes activities such as watering, collecting garbage, sowing, and harvesting. However, men perform certain activities such as pruning and sowing annual crops. Management practices include pruning trees, which is not done periodically, only when a heliophilous crop such as beans or maize is cultivated. No fertilization is carried out, and in more than half of the home gardens, plant litter and residuals of some crops are collected and burned. There is no composting of the organic waste generated in the domestic unit, since they use this waste to feed their animals. Weeding is done by hand with the help of hoe or a machete. No problems related to severe pest attacks were reported, because as farmers mentioned, their chickens serve as a biological control method when feeding on insects.

It is noteworthy that the ranch production model is the same as home gardens but on a larger scale. While in the monte only a hunting-gathering process is carried out.

C) Security and Food Consumption. A total of 127 foods consumed were registered, on average 60 foods per family. These foods were classified per origin (plant, animal, mineral, and industrial) and use (Table 2 and Table 3).

Origin of Food

From the 127 foods consumed, 70 (55\%) are produced. Of these 70, 55\% come from home garden,

Table 2 List and classification of foods consumed from animal, mineral and industrial origin.

\begin{tabular}{|c|c|c|}
\hline Industrialized & Animal Origin & Mineral Origin \\
\hline $\mathrm{Oil}^{*}$ & $\mathrm{Egg}^{*}$ & Salt $^{*}$ \\
\hline Sugar ${ }^{*}$ & Chicken $^{*}$ & Mineral condiment ${ }^{*}$ \\
\hline Instant ${ }^{*}$ coffee & Fish $^{*}$ & \\
\hline Soft drink ${ }^{*}$ & Pork $^{*}$ & \\
\hline Pasta $^{*}$ & Cheese ${ }^{*}$ & \\
\hline Bread $^{*}$ & Honey $^{*}$ & \\
\hline Cookies ${ }^{*}$ & Beef & \\
\hline Wheat flour & Shrimp & \\
\hline Tuna & Turkey & \\
\hline Milk & Lard & \\
\hline Ham & Hunted animals & \\
\hline Chocolate & Duck & \\
\hline Sausage & Zats Worm (Arsenura armida) & \\
\hline \multicolumn{3}{|l|}{ Mayonnaise } \\
\hline \multicolumn{3}{|l|}{ Tinned fruit } \\
\hline \multicolumn{3}{|l|}{ Tinned beans } \\
\hline Sauce & & \\
\hline
\end{tabular}

*Higher frequency of consumption. Source: Own elaboration. 
Table 3 List and classification of foods consumed from vegetal origin.

\begin{tabular}{|c|c|c|c|}
\hline Vegetal Origin & Common name & Scientific name & Family \\
\hline \multirow[t]{3}{*}{ Condiment } & Allspice $^{*}$ & Pimenta dioica (L.) Merril & Myrtaceae \\
\hline & Achiote $^{*}$ & Bixa orellana L. & Bixaceae \\
\hline & Cumin & Cuminum cyminum & Apiaceae \\
\hline \multirow[t]{3}{*}{ Forestry edible } & Guano (corazón) & Sabal japa & Arecaceae \\
\hline & Palma (corazón) & No identification & No identification \\
\hline & Ramón & Brosimum alicastrum Swartz & Moraceae \\
\hline \multirow[t]{35}{*}{ Fruit trees } & Lemon $^{*}$ & Citrus latifolia (Tan.) & Rutaceae \\
\hline & Banana $^{*}$ & Musa sp. & Musaceae \\
\hline & Orange ${ }^{*}$ & Citrus sinensis (L.) & Rutaceae \\
\hline & Coconut $^{*}$ & Cocos nucifera & Arecaceae \\
\hline & Tangerine $^{*}$ & Citrus reticulata & Rutaceae \\
\hline & Zapote mamey ${ }^{*}$ & Pouteria sapota (Jacq.) H.E. Moore \& Stearn & Sapotaceae \\
\hline & Plum & Spondias sp. & Anacardiaceae \\
\hline & Papaya & Carica papaya L. & Caricaceae \\
\hline & Pineapple & Ananas comosus (L.) Merr. & Bromeliaceae \\
\hline & Avocado & Persea americana & Lauraceae \\
\hline & Guaya & Melicoccus bijugatus & Sapindaceae \\
\hline & Mango & Mangifera indica & Anacardiaceae \\
\hline & Guaya de monte & Talisia olivaeformis (H.B. \& K.) Radlk. & Sapindaceae \\
\hline & Caimito & Chrysophyllum cainito & Sapotaceae \\
\hline & Tamarind & Tamarindus indica & Fabaceae \\
\hline & Anona & Annona purpurea & Annonaceae \\
\hline & Chicozapote & Manilkara sapota (L) Van Royen & Sapotaceae \\
\hline & Guava & Psidium guajava & Myrtaceae \\
\hline & Dragon fruit & Hylocereus undatus & Cactaceae \\
\hline & Soursop & Annona muricata & Annonaceae \\
\hline & Grapefruit & Citrus paradisi & Rutaceae \\
\hline & Apple & Malus domestica & Rosaceae \\
\hline & Bitter orange & Citrus aurantium & Rutaceae \\
\hline & Wild Anona & Annona primigenia & Annonaceae \\
\hline & Ciricote & Cordia dodecandra & Boraginaceae \\
\hline & Kolop & Talisia floresi Standley & Sapindaceae \\
\hline & Nance & Byrsonima crassifolia (L.) HBK. & Malpighiaceae \\
\hline & Zapote de monte & Pouteria unilocularis (Donn. Smith) Baehni & Sapotaceae \\
\hline & Pear & Pyrus communis & Rosaceae \\
\hline & Star fruit & Averrhoa carambola & Oxalidaceae \\
\hline & Chicozapote inj. & Unidentified & Sapotaceae \\
\hline & Chóoch & Pouteria glomerata & Sapotaceae \\
\hline & Cocoyol & Acrocomia aculeata (Jacq.) Lodd. Ex Mart. & Arecaceae \\
\hline & Grosella & Phyllanthus acidus & Phyllanthaceae \\
\hline & Saramuyo & Annona squamosa & Annonaceae \\
\hline \multirow[t]{7}{*}{ Grains } & Corn $^{*}$ & Zea mays & Poaceae \\
\hline & Beans $^{*}$ & Phaseolus vulgaris & Fabaceae \\
\hline & Rice $^{*}$ & Oryza sativa & Poaceae \\
\hline & Lentil $^{*}$ & Lens culinaris & Fabaceae \\
\hline & Chihua squash* & Cucurbita argyrosperma & Cucurbitaceae \\
\hline & Oats & Avena sativa & Poaceae \\
\hline & Cocoa & Theobroma cacao & Malvaceae \\
\hline
\end{tabular}

(continued on next page) 
(continued from previous page)

\begin{tabular}{|c|c|c|c|}
\hline Vegetal Origin & Common name & Scientific name & Family \\
\hline \multirow[t]{5}{*}{ Grains } & Ibes & Phaseolus lunatus var. Lunatus (Ibe) & Fabaceae \\
\hline & Peanut & Arachis hypogaea & Fabaceae \\
\hline & Green beans & Phaseolus sp. & Fabaceae \\
\hline & Xpelon bean & Vigna unguiculata & Fabaceae \\
\hline & Native soy & Glycine max & Fabaceae \\
\hline \multirow[t]{43}{*}{ Vegetables } & Onion $^{*}$ & Allium cepa & Alliaceae \\
\hline & Tomato $^{*}$ & Solanum lycopersicum L. & Solanaceae \\
\hline & Habanero pepper ${ }^{*}$ & Capsicum chinense & Solanaceae \\
\hline & Potato $^{*}$ & Solanum tuberosum & Solanaceae \\
\hline & Chaya $^{*}$ & Cnidoscolus aconitifolius & Euphorbiaceae \\
\hline & Chayote $^{*}$ & Sechium edule & Cucurbitaceae \\
\hline & Coriander ${ }^{*}$ & Coriandrum sativum & Apiaceae \\
\hline & Carrot $^{*}$ & Daucus carota & Umbelliferae \\
\hline & Cabbage $^{*}$ & Brassica oleracea var. Capitata & Brassicaceae \\
\hline & Yucca $^{*}$ & Manihot esculenta & Euphorbiaceae \\
\hline & Sweet potato ${ }^{*}$ & Ipomoea batatas & Convolvulaceae \\
\hline & Chili (various) $^{*}$ & Capsicum sp. & Solanaceae \\
\hline & Garlic $^{*}$ & Allium sativum & Alliaceae \\
\hline & Radish $^{*}$ & Raphanus sativus & Brassicaceae \\
\hline & Native squash ${ }^{*}$ & Cucurbita sp. & Cucurbitaceae \\
\hline & Zucchini $^{*}$ & Cucurbita pepo L. & Cucurbitaceae \\
\hline & Chives $^{*}$ & Allium schoenoprasum & Alliaceae \\
\hline & Milpa tomate ${ }^{*}$ & Lycopersicon esculentum P. Mill. & Solanaceae \\
\hline & Jalapeño pepper* & Capsicum annum & Solanaceae \\
\hline & Macal $^{*}$ & Xanthosoma sagittifolium & Araceae \\
\hline & Cucumber $^{*}$ & Cucumis sativus & Cucurbitaceae \\
\hline & Watermelon $^{*}$ & Citrullus lanatus & Cucurbitaceae \\
\hline & Indian mustard & Brassica juncea & Brassicaceae \\
\hline & Peas & Pisum sativum $\mathrm{L}$. & Fabaceae \\
\hline & Hierbamora & Solanum americanum Mill. & Solanaceae \\
\hline & Cantaloupe & Cucumis melo & Cucurbitaceae \\
\hline & Nopal & Opuntia sp. & Cactaceae \\
\hline & Sugarcane & Saccharum officinarum & Poaceae \\
\hline & Chipilín & Crotalaria longirostrata H.et.A & Fabaceae \\
\hline & Parsley & Petroselinum sativum & Apiaceae \\
\hline & Cauliflower & Brassica oleracea var. botrytis & Brassicaceae \\
\hline & Jícama & Pachyrhizus erosus & Fabaceae \\
\hline & Yam & Dioscorea rotundata & Dioscoriaceae \\
\hline & Lemon grass & Cymbopogon citratus & Poaceae \\
\hline & Peppermint & Mentha sp. & Lamiaceae \\
\hline & Jamaica & Hibiscus sabdariffa & Malvaceae \\
\hline & Beetroot & Beta vulgaris subsp. vulgaris convar. vulgaris & Chenopodiaceae \\
\hline & Lettuce & Lactuca sativa & Asteraceae \\
\hline & Momo & Piper auritum Kunth. & Piperaceae \\
\hline & Spinach & Spinacia oleracea & Chenopodiaceae \\
\hline & Alcaparra & No identification & No identification \\
\hline & Zucchini flower & Cucurbita pepo L. & Cucurbitaceae \\
\hline & Coconut flower & Cocos nucifera & Arecaceae \\
\hline
\end{tabular}

"Higher frequency of consumption. Source: Own elaboration with taxonomic data of FAO 2006; Herbario CICY 2010; LoezaDeloya et al. 2016; Macario and Sánchez 2003; Zizumbo et al. 2011. 
ranch, and/or milpa, while $33 \%$ is exclusively produced on home gardens, $7 \%$ on ranch and $5 \%$ in milpa. The purchased foods are 39 (34\%), and people get them more frequently in Distribuidora Conasupo S.A. de C.V. (Diconsa) and local grocery stores; they also get them at supermarkets, market, and sellers from the municipality. Athough six (5\%) of the 127 foods are produced regularly, people buy them in times of shortage, these are: maize (Zea mays), bean (Phaseolus vulgaris), egg, chicken (Gallus gallus domesticus), banana (Musa sp.) and tomato (Solanum lycopersicum). Finally, $6 \%$ is harvested or hunted in the forest or acabual. On average, the community that produces the most food is Narciso Mendoza (36), while the one that buys more food is 20 de Noviembre (29) (Figure 2).

\section{Consumption of Food}

The most frequently consumed foods are: oil, salt, corn (Zea mays), onion (Allium cepa), tomato (Solanum lycopersicum), sugar, beans (Phaseolus vulgaris), egg, rice (Oryza sativa), instant coffee, habanero pepper (Capsicum cbinense), potato (Solanum tuberosum), lemon (Citrus latifolia), chaya (Cnidoscolus aconitifolius), allspice (Pimienta dioica), chicken (Gallus gallus domesticus), chayote (Secbium edule), banana (Musa sp.), soft drink,

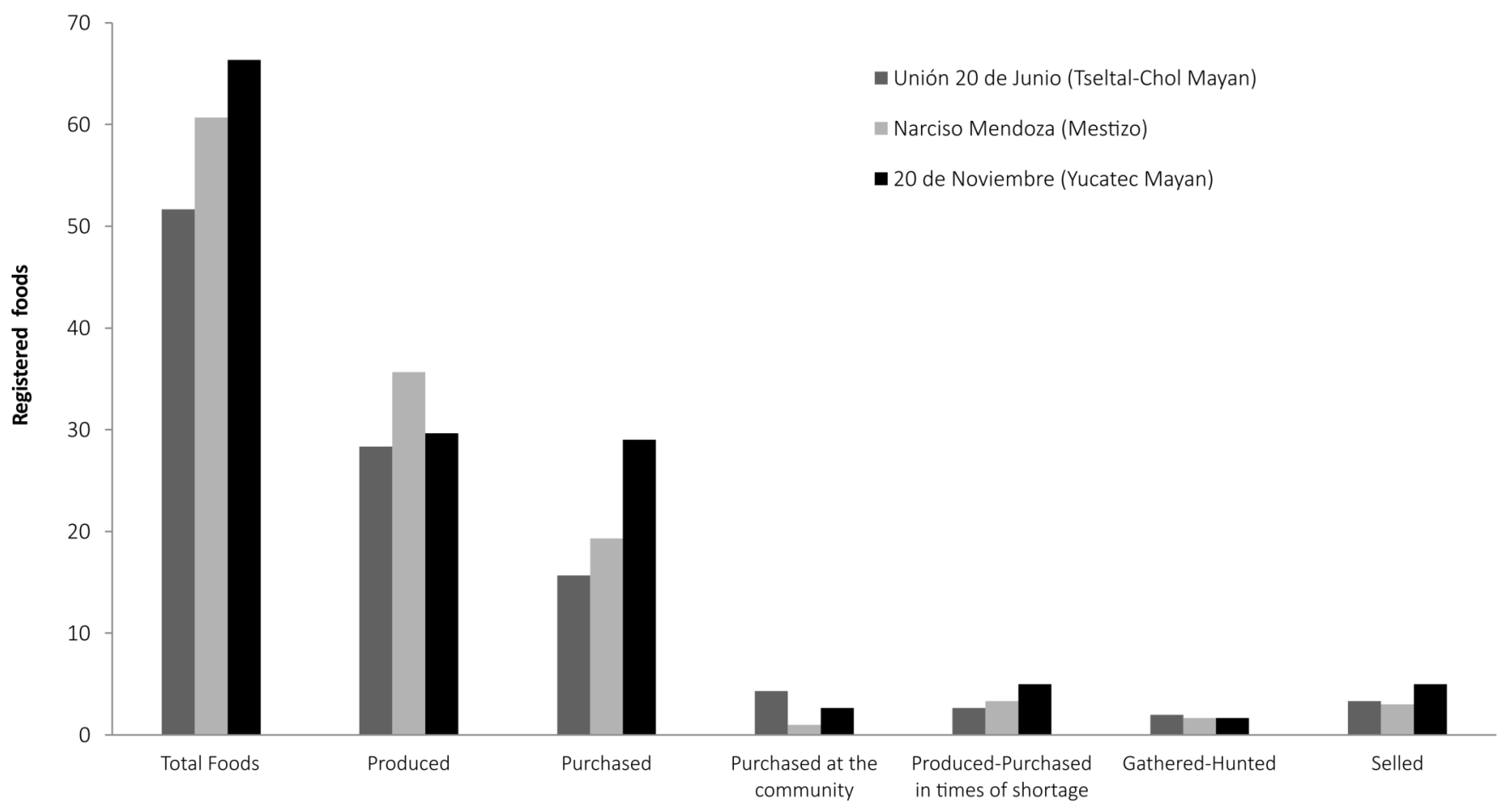

cilantro (Coriandrum sativum), carrot (Daucus carota), cabbage (Brassica oleracea), yucca (Manibot esculenta), sweet potato (Ipomoea batatas), orange (Citrus sinensis), chili (various), fish (unidentified), garlic (Allium sativum), coconut (Cocos nucifera), pasta, pork (unidentified), bread, lentil (Lens culinaris), radish zucchini (Cucurbita pepo), chives (Allium schoenoprasum), cheese, milpa tomato (Lycopersicon esculentum), cbibua (Cucurbita argyrosperma), and jalapeño pepper (Capsicum annum) (Figure 3). It's important to emphasize that even though habanero pepper (Capsicum cbinense) is one of the most consumed foods, only one third of the families (Yucatec Mayan) cultivate it.

The main sources of animal protein in the communities are egg and chicken (Gallus gallus domesticus), followed by pork (unidentified). Animal husbandry takes place in home gardens. People can also buy meat in the community and occasionally in the municipality.

In Figure 4, we can see that the most consumed foods are bought in the store (41\%), such as oil, salt, onion, tomato, sugar, rice, coffee, and potato, whereas $42 \%$ of the most consumed foods such as vegetables, fruit, cereals, legumes, condiments, eggs and chicken, come from home gardens, ranch, and/or milpa. The (Raphanus sativus), native squash (Cucurbita sp.),

Figure 2 Origin of food: Differences between communities. 


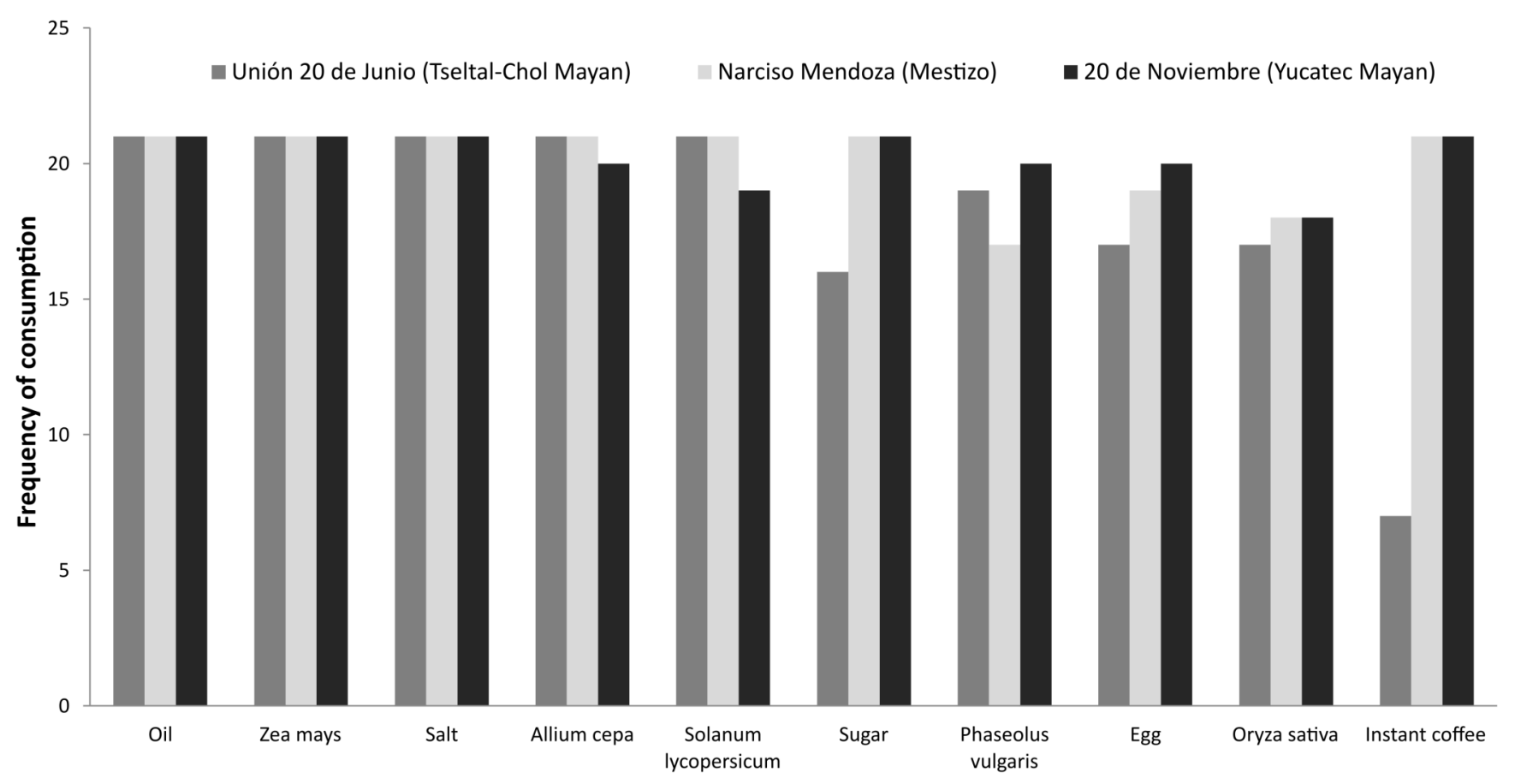

Figure 3 Foods with higher frequencies of consumption.

other $16 \%$ is produced in the home garden $(8 \%)$ or milpa $(7 \%)$. However, in times of shortage these foods are purchased at the store. By contrast, 31\% of foods with lower frequency of consumption come from home gardens and/or ranch and only 13\% come exclusively from home gardens, due to the temporary nature of these foods.

\section{Culturally Appropriate Food: Particularities in Food Consumption according to the Culture}

There are particularities in food consumption among ethnic groups (Table 4). Since the three populations are migrants, various plant species have been brought from their place of origin, thus people's consumption habits are determined by those places and the adaptation to the environment in which they now live. For example, mestizo families from Veracruz and Tabasco consume shrimp, cacao (Theobroma cacao), sugar cane (Saccharum officinarum), chipilín (Crotalaria longirostrata) and now they also include ramón (Brosimum allicastrum) and ciricote (Cordia dodecandra) (foods they started to consume when they arrived to the region) to their diet. Yucatec Mayan communities particularly consume achiote (Bixa orellana), ibes (Phaseolus lunatus), yam (Dioscorea rotundata), and more processed foods such as soda, crackers, wheat flour, and tuna. The community Unión 20 de Junio is peculiar since it is located furthest from the municipality $(43 \mathrm{~km})$. People here do not consume as much industrialized food as in the other communities, and they do not consume dairy products.

\section{Temporality of Food}

Home gardens are a highly important source of food since a lot of products are obtained here. However, milpa is more important since it is in this system where

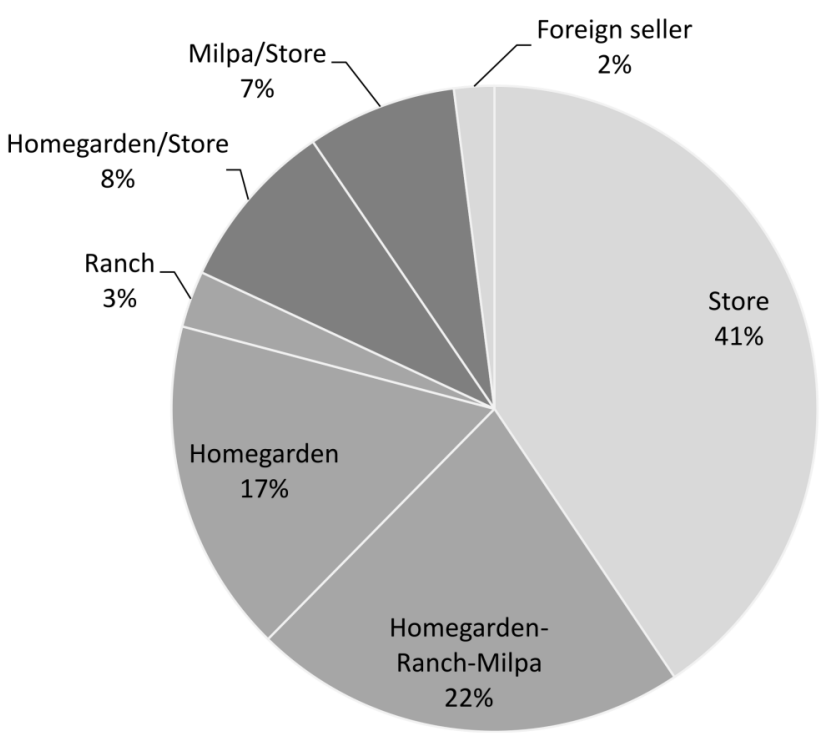

Figure 4 Origin of foods with higher frequencies of consumption. 
Table 4 Particularities in food consumption according to the culture.

\begin{tabular}{ll}
\hline Community-Indigenous Group & Foods \\
\hline Unión 20 de Junio (Tseltal-Chol Mayan) & $\begin{array}{l}\text { Chayote, banana, Indian mustard, mango, green or tender beans, anona, lemon } \\
\text { grass, hunted animals, and momo. There was no consumption of dairy products. } \\
\text { Orange, chili (various), yucca, native squash, jalapeño pepper, macal, shrimp, } \\
\text { Narciso Mendoza (Mestizo) }\end{array}$ \\
$\begin{array}{l}\text { avocado, cocoa, turkey, sugarcane, chipilín, parsley, jicama, dragon fruit, cumin, } \\
\text { grapefruit, ramón and ciricote. } \\
\text { Lemon, soft drink, coriander, cabbage, radish, zucchini, cheese, milpa tomato, } \\
\text { cookies, achiote, watermelon, tortillas made of wheat flour, plum, tuna, oats, } \\
\text { peas, ibes, melón, milk and yam. }\end{array}$
\end{tabular}

See Table 3 for scientific names.

the most commonly eaten foods are cultivated, such as maize, beans, squash, and chili.

The results of this study indicate that as long as the drought is not excessive, there is food availability into the home gardens and ranches all year. From March to June there is increased availability of produce from fruit trees. The harvesting of food in the milpa begins at the end of August with vegetables such as native cucumber, and ends in April with tubers like sweet potato (this period coincides with the rainy season). The period of food vulnerability specified by AlayónGamboa (2014a), coincides with the results of this study, as well as the timing of the preparation of the terrain and the development of the milpa (Table 5).

The local maize production is insufficient due to long periods of drought. In the community of Narciso Mendoza, we recorded that the average yield is $0.73 \mathrm{t} / \mathrm{ha}$, while the annual consumption per family is 1.9 t. Thus, families need to buy 1.17 t to satisfy their corn consumption, as they also use this crop to feed their animals. Given this problem, farmers take advantage of the rainfall in January, which allows agricultural production in autumn-winter, event that is colloquially known as tornamil by farmers. Some farmers have even opted to plant maize, beans, and squash within the home garden.

D) Transformation and Commercialization. There is also, but on a smaller scale, an important acquisition of locally produced food. The following foods are bought or shared between families and neighbors, and even sold in nearby communities: egg, lemon (Citrus latifolia), chayote (Sechium edule), banana (Musa sp.), cilantro (Coriandrum sativum), yucca (Manihot esculenta), sweet potato (Ipomoea batatas), orange (Citrus sinensis), coconut (Cocos nucifera), pork (unidentified), radish (Raphanus sativus), zucchini (Cucurbita pepo), milpa tomato (Lycopersicon esculentum), chihua (Cucurbita argyrosperma), achiote (Bixa orellana), macal (Xanthosoma sagittifolium), mandarine (Citrus reticulata), Mexican plum (Spondias sp.), hierbamora (Solanum americanum), caimito (Chrysophyllum cainito), chipilín (Crotalaria longirostrata), chicken (Gallus gallus domesticus), carrot (Daucus carota), cabbage (Brassica oleracea), chili (various) (Capsicum sp.), zapote mamey (Pouteria sapota), Indian mustard (Brassica juncea), pineapple (Ananas comosus), mangoe (Mangifera indica), ibes (Phaseolus lunatus), lettuce (Lactuca sativa), and grosella (Phyllanthus acidus).

Some foods are commercialized through foreign intermediaries who are responsible for collecting the products in the communities. There are also producer societies like the ones who produce allspice (Pimienta dioica) and honey, which are already organized to sell their products. The most important commercialized foods are: lemon (Citrus latifolia), allspice (Pimienta dioica), cilantro (Coriandrum sativum), radish (Raphanus sativus), zucchini (Cucurbita pepo), mandarine (Citrus

Table 5 Food production temporality in traditional agroecosystems. $\mathrm{T}=$ production time; $\mathrm{P}=$ moderate production; Empty $=$ no food availability; and $\mathrm{R}=$ presence of rainfall.

\begin{tabular}{|c|c|c|c|c|c|c|c|c|c|c|c|c|}
\hline & Jan & Feb & Mar & Apr & May & Jun & Jul & Aug & Sep & Oct & Nov & Dec \\
\hline Milpa & $\mathrm{T}$ & $\bar{T}$ & $\bar{T}$ & $T$ & & & & & $\bar{T}$ & $\mathrm{~T}$ & $\bar{T}$ & \\
\hline Home garden/Ranch & $\mathrm{P}$ & $P$ & $\mathrm{~T}$ & $\mathrm{~T}$ & $\mathrm{~T}$ & $\mathrm{~T}$ & $P$ & $P$ & $P$ & $P$ & $P$ & $P$ \\
\hline Alayón-Gamboa, 2014 & $\mathrm{~T}$ & $\mathrm{~T}$ & $\mathrm{~T}$ & $\mathrm{~T}$ & & & & & $\mathrm{~T}$ & & $\mathrm{~T}$ & $\mathrm{~T}$ \\
\hline Rainy season & $\mathrm{R}$ & & & & & $\mathrm{R}$ & $\mathrm{R}$ & $\mathrm{R}$ & $\mathrm{R}$ & $\mathrm{R}$ & $\mathrm{R}$ & \\
\hline
\end{tabular}

Source: Own elaboration based on the information obtained from the field search and Alayón-Gamboa (2014a). 
reticulata), honey, cucumber (Cucumis sativus), and pitahaya (Hylocereus undatus).

E) Agricultural Policies. Existing organizations in food production and marketing are regional, some families from Narciso Mendoza and Unión 20 de Junio (La Mancolona) are part of the organization for the commercialization of pepper Xanich S.P.R. of R.L. which has 47 partners from 11 communities. On the other hand, there is the Union of Ecological Apiculture Societies of Calakmul (USAEC), which sells bulk honey to different buyers and commercial chains. USAEC groups around 250 beekeepers distributed in 25 communities, including Narciso Mendoza.

Regrding participation in decision-making, the only participation is with respect to carrying out some programs implemented by non-government organizations, but there is no influence on local public policies about food production or food security.

\section{Discussion}

A) Access to Resources

The greatest vulnerability from lack of access to a vital resource comes during periods of drought in Calakmul the area. However, the families practicing traditional agriculture have adapted to the local environment with a flexible strategy where losses in one subsystem are replaced by others with similar functions, as described by Vallejo et al. (2011).

The inhabitants of Calakmul, due to migrations and long periods of drought, are still in the process of learning and adapting to the conditions of the forest. Our finding resonates with what Neulinger et al. (2013) found because they mention that migrants try strategies of cultivation of species that are native to their place of origin in order to guarantee their food supply. Their knowledge about cultivation of some plant species that grow in the area is still incipient (Municipio de Calakmul and Proyecto Prosureste (GPZ-CONANP) 2015) and nowadays they are still experimenting with species that they bring from their place of origin, such as cocoa and coffee.

\section{B) Production model}

Traditional agroecological management practices are still preserved, native species are still being cultivated, and people do not rely heavily on external inputs to continue their production, which is also described by Chi-Quej et al. (2014). However, there is an evident need to reinforce the empirical knowledge of the farmers with current agroecological techniques and specific technical advice.

The change from the milpa system to mechanized cultivation of maize could lead to a greater dependence on the use of non-renewable energies, and by doing so, energy efficiency and sustainability could be reduced, making the agroecosystems more vulnerable as mentioned by Alayón-Gamboa (2014b).

A study conducted by Alayón-Gamboa (2014b) showed that traditional agroecosystems in Calakmul are more energy-efficient compared to agricultural systems in transition towards the technification, given the fact that traditional agroecosystems are based on the synergistic use of solar energy and family workforce (Alayón-Gamboa 2014b; Jianbo 2006). Similarly, Altieri (1999a) states that traditional agroecological systems are energy efficient and they have more stable levels of production per unit area over time, compared to those of intensive farming systems.

According to Chi-Quej et al. (2011) it is necessary to take into account and to carry out international and national policies as strategies of local development. The Ecological Management of the Territory Program of the Calakmul Municipality and the Strategy for the Conservation and Sustainable Use of Biodiversity in the State of Campeche indicate actions for the sustainable use of biodiversity, as well as the Aichi Biodiversity Targets which are part of the Strategic Plan for Biodiversity 2011-2020. However, it is still necessary to implement in the communities the actions outlined in these documents.

\section{C) Safety and Food Consumption}

Cahuich-Campos (2012) found that farmers obtain about $77 \%$ of the ingredients necessary for the preparation of their food through these production systems, which differs from our results, since we found that $55 \%$ of the food that is produced comes from the home garden, the ranch and/or the milpa. This suggests that they are inherently related production systems. In this sense, food production is a network type system as it relies on several systems (Rosado 2012). Alayón-Gamboa (2014b) points out that there is a high degree of energy exchange between these agroecosystems. According to Terán (2011), milpa serves as the organizing axis for the rest of the production systems, since it is the arranging element of culture, due to each socio-cultural system (family or community) has its own dynamics, 
establishes objectives and is organized so that its productive systems work and can be reproduced. Our results are similar to the ones found by AlayónGamboa (2014a), and Terán and Rasmussen (2009), who state that historically, and from the productive point of view, home gardens have played a strategic role for the survival of families, offering complementary food resources to milpa in good years, and essential ones in years of scarcity. Thus, the multiple use strategy of natural resources contributes to improve farmers and their families in their quality of life (Cahuich-Campos 2012).

As mentioned by Chi-Quej et al. (2014) and our results, not all species have the same cultural importance in the three communities, as factors such as the preference for consumption, the type of dishes they prepare and their purchasing power (linked to other economic activities or government support) are combined.

At the present time, the change in eating habits threatens the permanence of home gardens (Chi-Quej et al. 2011). Rosado (2012) mentions that when family gardens are lost, other traditional production systems, such as milpa, are lost as well, and the region diminishes its probability of achieving food sufficiency and sovereignty.

It is necessary to preserve and consume traditional foods. An example of this was the publication of the Calakmul Regional Recipes, whose objective is to spread and support the culinary culture (Flores and Gurri 2005).

\section{D) Transformation and Commercialization}

As our results indicate, there is a small-scale commercialization and intermediaries generally control it, although there are producers who already form part of associations that sell their products or even some of them sell them independently. Existing mechanisms could be replicated and adapted for local marketing of surplus products from TAS. The Ecological Management of the Territory Program of the Calakmul Municipality mentioned that one of the challenges is to identify commercialization channels so that the surplus products of TAS could be sold (Calakmul Municipality and Project Prosureste (GPZCONANP) 2015).

\section{E) Agricultural Policies}

On the other hand, $\mathrm{FS}_{\mathrm{v}}$ is threatened by government social programs that scatter the means of food production and food consumption by the inhabitants.
The net impacts of these programs seems to be in the opposite direction to the objective for which they were designed and implemented (Olvera et al. 2016; Pérez et al. 2012). For example, studies from Pérez et al. (2012) and Olvera et al. (2016) reveal that the usual diet of rural communities has been affected by the introduction of modern processed foods. This is related to the increasing risks of diseases like obesity and type 2 diabetes mellitus. It has been observed that changes in diet are associated with the availability of money obtained in government social programs or by labor emigration (Olvera et al. 2016).

Alayón-Gamboa (2014a) mentions that high government support towards Yucatec Mayan communities by promoting artisanal activities, is discouraging the importance of agriculture as a means of diversifying income streams. The community 20 de Noviembre is an example of this situation because families there buy more food than the families from the other communities, and this situation is also reflected in the plant composition of their gardens compared to the other study sites. In the three communities that are part of this study, despite having highly diverse home gardens, family consumption is focused on few plant species, as Cahuich-Campos (2012) and Alayón-Gamboa (2014a) also conclude.

Given this scenario, Moreno et al. (2013) highlight the need to create and apply policies based on the context and the biocultural richness of the region. Rosset and Martinez (2004) suggest that government support should be given to farmers to stay on their land, conserve active rural economies, promote soil conservation, help maintain sustainable agricultural practices, and promote direct sales to local consumers and the adoption of a healthy diet (Pérez et al. 2012).

\section{Conclusions}

TAS are a type of ecological agriculture, and represent an important source of food for the dietary needs of the local population. It is necessary to reinforce the production model in TAS and to emphasize the importance of those modes of production among families to ensure their permanence.

The production and consumption of food are embedded in a complex network that responds to changes in the pattern of rainfall and exogenous factors, such as government programs that are not in line with the reality of the social actors and local culture. 
TAS constitutes an important life strategy for the peasant families. However, to ensure the continued contribution of the modes to FSv, it is necessary to streamline the actions of the stakeholders that share the same objective. Some of these participants are the academic sector, governmental organizations, nongovernmental organizations operating in the area, management of the Biosphere Reserve and peasant organizations. Ensuring the livelihood provision of the local population can relieve the pressure on the remaining areas of primary forest.

It would be advisable to orientate future research to highlight the ecological importance of TAS and create adaptive production strategies due to changes in rainfall patterns in order to maintain and increase the productivity of TAS.

Furthermore, it would be appropriate to encourage diversification in the consumption of plant foods, because despite the fact of having highly diverse productive spaces, families focus their consumption on few species, which leads to a dependency because they do not always have the necessary conditions to achieve its production and self-sufficiency.

Agricultural production must be focused on sustainable practices that allow the existence of natural ecological processes, conservation of biodiversity and at the same time provide diverse, nutritious and culturally appropriate food for the population. To this aim, the strengthening and promoting of agroecological practices play a key role.

While it is necessary to meet the basic food needs of the population, it is also essential to ensure the sustainability of this provision as well as the maintenance of other ecosystem services. To achieve this, it is necessary to create a real coordination between the actions proposed in the Ecological Ordination Program of the Municipality of Calakmul and the Strategy for the Conservation and Sustainable use of Biodiversity in the State of Campeche with the actions implemented with the Secretariat of Agriculture, Livestock, Rural Development, Fisheries and Food (SAGARPA), the Ministry of Rural Development of the State of Campeche, and the corresponding municipal departments.

It is essential to guide government policies and programs towards the promotion of local economic development with the active participation of these populations through local organizations. One way to achieve this development in rural areas is by creating local production and consumption circuits where farmers' families sell their products and buy what they need in local populations, as there is potential production that can supply demand at the community level. Such a task would allow the conservation and improvement of TAS.

The social unit for the production and organization of work is the family. It may be significant to consider scaling organizational leadership and decision-making at the community level for commercialization, which involves the creation and support of local markets, direct sales to the consumer, or with a minimum of intermediaries.

\section{Acknowledgements}

We thank Dr. Fabien Sylvain Jacky Charbonnier for his valuable comments and contributions to this article. We also thank the participation of the families in Calakmul who welcomed us in their homes and shared part of their life with us. Map collaboration by Gisel Puc is gratefully acknowledged. Finally, we would like to thank Albert Chan Dzul for bringing us closer to the families and to Mario Alberto Santiago Ortega for his support in the field.

\section{Declarations}

Permissions: Permission was requested from the families involved, ensuring their free and informed participation.

Sources of funding: None declared.

Conflicts of Interest: None declared.

\section{References Cited}

American Academy of Pediatrics, Section on Breastfeeding. 2012. Breastfeeding and the Use of Human Milk. Pediatrics 129:e827-e841.

DOI:10.1542/peds.2011-3552.

Alayón-Gamboa, J. 2014a. Contribución del Huerto Familiar a la Seguridad Alimentaria de las Familias Campesinas de Calakmul, Campeche. In El huerto Familiar: Un Sistema Socioecológico y Biocultural para Sustentar los Modos de Vida Campesinos en Calakmul, Mexico, edited by J. Alayón-Gamboa and A. Morón, pp. 15-40. El Colegio de la Frontera Sur, Mexico.

Alayón-Gamboa, J. 2014b. Sustentabilidad de la Agricultura Tradicional y el Impacto en su Transformación: El Caso de Calakmul, Campeche. In Sociedady Ambiente en Mexico: Áreas Naturales Protegidas y Sustentabilidad, edited by M. Pinkus, pp. 
211-236. Universidad Nacional Autónoma de Mexico, Centro Peninsular en Humanidades y Ciencias Sociales, Mexico.

Altieri, M. 2009a. Applying Agroecology to Enhance the Productivity of Peasant Farming Systems in Latin America. Environment, Development and Sustainability 1:197-217.

Altieri, M. 2009b. Agroecología, Pequeñas Fincas y Soberanía Alimentaria. Ecología Política 38:25-35.

Altieri, M. A., and C. I. Nicholls. 2013. Agroecología y Resiliencia al Cambio Climático: Principios y Consideraciones Metodológicas. Agroecología 8:720.

Barbosa, S., D. Molina, G. Escalona, and E. Bello. 2010. Organización y Ecoturismo en Ejidos del Sureste Mexicano. Revista de Estudios Agrarios 44:141-160.

Balvanera, P., and H. Cotler. 2009. Estado y Tendencias de los Servicios Ecosistémicos. In Capital Natural de Mexico, Vol. II: Estado de Conservación y Tendencias de Cambio, edited by CONABIO, pp. 185-245. Comisión Nacional para el Conocimiento y Uso de la Biodiversidad, Mexico.

Bello, E., and E. I. J. Estrada. 2011. Cultivar el Territorio Maya. Conocimiento y Organización Social en el Uso de la Selva. El Colegio de la Frontera Sur and Universidad Iberoamericana, Mexico.

Bohn, J., A. Stewart, W. Diemont, J. Gibbs, S. Stehman, and J. Mendoza. 2014. Implications of Mayan Agroforestry for Biodiversity Conservation in the Calakmul Biosphere Reserve, Mexico. Agroforestry Systems 88:269-285.

Bovin, P., J. Pat, and B. Schmook. 2000. Presentación de Avances de Investigación: Aspecto

Socioeconómico. In Tendencias de Cambio en El Uso de Suelo por los Factores Socioeconómicos, Naturales y Técnicos en la Región de Calakmul, Campeche, edited by J. M. Pat and V. Ku, pp. 24-102. El Colegio de la Frontera Sur, Mexico.

Cahuich-Campos, D. 2012. El Huerto Maya y la Alimentación Cotidiana de las Familias Campesinas de X-Mejía, Hopelchén, Campeche. In El huerto familiar del sureste de Mexico, edited by R. Mariaca, pp. 197-229. Secretaría de Recursos Naturales y Protección Ambiental del Estado de Tabasco. El Colegio de la Frontera Sur, Mexico. Casanova-Lugo, F., J. Petit-Aldana, and J. Solorio-
Sánchez. 2011. Los Sistemas Agroforestales como Alternativa a la Captura de Carbono en el Trópico Mexicano. Revista Chapingo. Serie Ciencias Forestales y del Ambiente 17:133-143.

Chablé-Can E., D. Molina-Rosales, J. Mendoza, and M. Kú-Quej. 2015. Proceso Participativo: Una Propuesta Metodológica para la Elaboración de Estrategias Relacionadas con REDD+. El Colegio de La Frontera Sur, Mexico.

Chi-Quej, J., G. Rivas, I. Gutiérrez, G. Detlefsen, A. Alayón-Gamboa, and V. Ku-Quej. 2011. Los Huertos Familiares y su Contribución a la Seguridad Alimentaria en Campeche, Mexico. Paper Presented at the 3rd Congreso Latinoamericano de Agroecología. Sociedad Científica Latinoamericana de Agroecología. Universidad Autónoma Chapingo, Mexico.

Chi-Quej, J., J. Alayón-Gamboa, G. Rivas, I. Gutiérrez, G. Detlefsen, and V. Ku-Quej. 2014. Contribución del Huerto Familiar a la Economía Campesina en Calakmul, Campeche. In El Huerto Familiar: Un Sistema Socioecológico y Biocultural para Sustentar los Modos de Vida Campesinos en Calakmul, Mexico, edited by J. Alayón-Gamboa and A, Morón, pp. 75-90. El Colegio de la Frontera Sur. Mexico.

CONAPO. 2010. Índice de Marginación por Localidad 2010. Consejo Nacional de Población, Mexico.

Cuéllar, M., and E. Sevilla. 2009. Aportando a la Construcción de la Soberanía Alimentaria desde la Agroecología. Ecología política 38:43-51.

Ellis, E. A., and B. L. Porter. 2007. Agroforestería en la Selva Maya: Antiguas Tradiciones y Nuevos Retos. In Los Nuevos Caminos de la Agricultura: Procesos de Conversión y Perspectivas, edited by J. A., González, R. S., Del Amo, and G. F. Gurri, pp. 213-242. Universidad Iberoamericana, Mexico.

Flores, V., and F. Gurri. 2005. Recetario Regional de Calakmul, Campeche. El Colegio de la Frontera Sur. Consejo Nacional para la Cultura y las Artes. Instituto Nacional de Antropología e Historia, Mexico.

FAO. 2006. Calendario de Cultivos. América Latina y el Caribe. Food and Agriculture Organization, Rome, Italy.

Gliessman, S. 2007. Agroecology. The Ecology of Sustainable Food Systems, $2^{\text {nd }}$ edition. CRC Press, Boca Raton, FL. 
Gurri, F. D., J. A. Alayón, and D. O. Molina. 2002. Adaptabilidad en Poblaciones Mayas y Poblaciones Migrantes de Calakmul, Campeche. El Colegio de la Frontera Sur (ECOSUR), Mexico.

INECOL. 1999. Programa de Manejo de la Reserva de la Biósfera Calakmul. 1era Edición. Unidad de Participación Social, Enlace y Comunicación, Instituto Nacional de Ecología, Mexico.

INEGI. 2010. Censo General de Población y vivienda. Principales Resultados por Localidad. Instituto Nacional de Estadística, Geografía e Informática, Campeche, Mexico.

INEGI. 2012. Censo Agropecuario. VII Censo Agrícola, Ganadero y Forestal 2007. Instituto Nacional de Estadística, Geografía e Informática, Mexico.

Herbario del Centro de Investigación Científica de Yucatán (CICY). 2010. Flora de la Península de Yucatán. Available at: http://www.cicy.mx/sitios/ flora\%20digital/. Accessed on August 15, 2016.

Hernández, X. E. 1985. Xolocotria. Obras de Efraim Hernández Xolocotzi. Tomo I. Geografía Agrícola, Universidad Autónoma Chapingo, Mexico.

Hoddinott, J. 2001. Food security in practice. Methods for Rural Development Projects. International Food Policy Research Institute, Washington, DC.

Huntington, H.P. 2000. Using Traditional Ecological Knowledge in Science: Methods and Applications. Ecological Applications 10:1270-1274.

Jianbo, L. 2006. Energy Balance and Economic Benefits of Two Agroforestry Systems in Northern and Southern China. Agriculture Ecosystems and Environment 116:255-262.

Loeza-Deloya, V., N. Uzcanga-Pérez, A. CanoGonzález, G. Ramírez-Jaramillo, J. Ramírez-Silva, and Y. Aguilar-Duarte. 2016. Cadenas de Importancia Socioeconómica para el Desarrollo Agrícola e Industrial de la Península de Yucatán, Mexico. Agroproductividad 9:3-8.

Macario, P., and L. Sánchez. 2003. Lista Florística de Especies Presentes en la Vegetación Secundaria del Ejido X-Hazily Anexos. ECOSUR, SISIERRA, UADY and Clark University, Mexico.

Martin, J. F., E. D. Roy, S. Diemont, and B. G. Ferguson. 2010. Traditional Ecological Knowledge (TEK): Ideas, Inspiration, and Designs for Ecological Engineering. Ecological Engineering 36:839-849.

Martínez, E., and C. Galindo. 2002. La Vegetación de
Calakmul, Campeche, Mexico: Clasificación, Descripción y Distribución. Boletín de la Sociedad Botánica de Mexico 71:7-32.

Miles, M. B., and A. M. Huberman. 1994. Qualitative Data Analysis: An Expanded Sourcebook, $2^{\text {nd }}$ edition. Sage, Thousand Oaks, CA.

Moreno-Calles, A. I., V. M. Toledo, and A. Casas. 2013. Los Sistemas Agroforestales Tradicionales de Mexico: Una Aproximación Biocultural. Botanical Sciences 91:375-398.

Moreno-Calles, A. I., V. J. Galicia-Luna, A. Casas, V. M. Toledo, M. Vallejo-Ramos, D. Santos-Fita, and A. Camou-Guerrero. 2014. La Etnoagroforestería: El estudio de los Sistemas Agroforestales Tradicionales de Mexico. Etnobiología 12:1-6.

Municipio de Calakmul and Proyecto Prosureste (GPZ-CONANP). 2015. Programa de Ordenamiento Ecológico del Territorio del Municipio de Calakmul, Campeche. Un Estudio Enfocado a las Funciones Ecológicas del Paisaje. Gobierno del Estado de Campeche, Mexico.

Nair, P. K. R. 1993. An Introduction to Agroforestry. Kluwer Academic Publisher, Dordrecht, Netherlands.

Neulinger, K., C. Vogl and J.A. Alayón-Gamboa. 2013. Plant Species and Their Uses in Homegardens of Migrant Maya and Mestizo Smallholder Farmers in Calakmul, Campeche, Mexico. Journal of Ethnobiology 33:105-124.

Nicholls, C. I., M. A. Altieri, A. Henao, R. Montalba, and E. Talavera. 2015. Agroecología y el Diseño de Sistemas Agricolas Resilientes al Cambio Climático. REDAGRES and SOCLA, Lima, Perú.

Noriega-Trejo, R., and M. Arteaga. 2010. Síntesis de los Tipos de Vegetación Terrestre. In La Biodiversidad en Campeche: Estudio de Estado, edited by G. J. Villalobos-Zapata and J. Mendoza-Vega, pp. 730. Comisión Nacional para el Conocimiento y Uso de la Biodiversidad (CONABIO), Gobierno del Estado de Campeche, Universidad Autónoma de Campeche, El Colegio de la Frontera Sur, Campeche, Mexico.

Ortega-Cerda, M., and M. Rivera-Ferre. 2010. Indicadores Internacionales de Soberanía Alimentaria. Nuevas Herramientas para una Nueva Agricultura. Revista Iberoamericana de Economía Ecológica 14:53-77.

Olvera, B., B. Schmook, C. Radel, and D. A. Nazar. 
2016. Efectos Adversos de los Programas de Apoyo Alimentario en los Hogares Rurales de Calakmul, Campeche. Estudios sociales 49:13-45.

Patton, M.Q. 2002. Qualitative Research and Evaluation Methods, $3^{\text {rd }}$ edition. Sage, Thousand Oaks, CA.

Perfecto, I., J. Vandermeer, and A. Wright. 2009. Nature's Matrix. Linking Agriculture, Conservation and Food Sovereignty. Earthscan, London, United Kingdom.

Pérez, O., A. Nazar, B. Salvatierra, S. Pérez-Gil, L.

Rodríguez, M. Castillo, and R. Mariaca. 2012.

Frecuencia del Consumo?de Alimentos Industrializados Modernos en la Dieta Habitual de Comunidades Mayas de Yucatán, Mexico. Estudios Sociales 20:156-184.

Pool, L., S. Cortina, and P. Macario. 2000. Presentación de Avances de Investigación: Aspecto Físico Biótico. In Tendencias de Cambio en el Uso de Suelo por los Factores Socioeconómicos, Naturales y Técnicos en la Región de Calakmul, Campeche, edited by J-J. Pat and V. Ku, pp. 24-102. El Colegio de la Frontera Sur, Mexico.

Pretty, J., J. Morrison, and R. Hine. 2003. Reducing Food Poverty by Increasing Agricultural Sustainability in Developing Countries. Agriculture, Ecosystems and Environment 95:217-234.

Rosado, F. 2012. Los Huertos Familiares, Un Sistema Indispensable para la Soberanía y Suficiencia Alimentaria en el Sureste de Mexico. In El buerto Familiar del Sureste de Mexico, edited by R. Mariaca, pp. 350-360. Secretaría de Recursos Naturales y Protección Ambiental del Estado de Tabasco and El Colegio de la Frontera Sur, Mexico.

Rosset, P., and M. E. Martínez. 2004. Soberanía Alimentaria: Reclamo Mundial del Movimiento Campesino. Food Sovereignty: Global Rallying Cry of Farmer Movements. Institute for Food and Development Policy Backgrounder 9:1-4.

Sánchez, P. A. 1995. Science in Agroforestry. Agroforestry Systems 30:5-55.

Senanayake, R. 2003. Forestería Análoga: Una Alternativa a Rozar y Simplificar. Revista de Agroecología LEIS A 16:14-15.

Sodhi, N. S., and P. R. Ehrlich. 2010. Conservation Biology for All. Oxford University Press, New York,
NY.

Soto-Pinto, L., M. Anzueto, J. Mendoza, G. Jiménez, and B. De Jong. 2010. Carbon Sequestration through Agroforestry in Indigenous Communities of Chiapas, Mexico. Agroforestry Systems 78:39-51.

Terán, S. 2011. Milpa, Biodiversidad y Diversidad Cultural. In Biodiversidad y Desarrollo Humano en Yucatán, edited by R. Durán and M. Méndez, pp. 54-56. CICY, PPD-FMAM, CONABIO, SEDUMA, Mexico.

Terán, S. and C. Rasmussen. 2009. La milpa de los Mayas, $2^{\text {nd }}$ edition. Universidad Nacional Autónoma de Mexico, Mexico.

Vallejo, M., F. Gurri, and D. Molina, 2011. Agricultura Comercial, Tradicional y Vulnerabilidad en Campesinos. Política y Cultura 36:71-98.

Vía Campesina. 1996. Declaración sobre la Soberanía Alimentaria de los Pueblos. Cumbre Mundial de la Alimentación. II Conferencia Internacional de la Vía Campesina. Tlaxcala, Mexico. Available at: http://www.viacampesina.org. Accessed on November 11, 2015.

Villalobos-Zapata, G. J., and J. Mendoza Vega. 2010. La Biodiversidad en Campeche: Estudio de Estado. Comisión Nacional para el Conocimiento y Uso de la Biodiversidad (CONABIO), Gobierno del Estado de Campeche, Universidad Autónoma de Campeche, El Colegio de la Frontera Sur, Mexico.

Verchot, L., M. Van Noordwijk, S. Kandji, T. Tomich, C. Ong, A. Albrecht, J. Mackensen, C. Bantilan, K. Anupama, and C. Palm. 2007. Climate Change: Linking Adaptation and Mitigation through Agroforestry. Mitigation and Adaptation Strategies for Global Change 12:901-918.

Wojtkowski, P. 2002. Agroecological Perspectives in Agronomy, Forestry and Agroforestry. Science publishers, Enfield, NH.

Zizumbo, D., P. Colunga, F. May, J. Martínez, and J. Mijangos. 2011. Recursos Fitogenéticos para la Alimentación y la Agricultura. In Biodiversidady Desarrollo Humano en Yucatán, edited by R. Durán, and M. Méndez, pp. 334-339. CICY, PPD-FMAM, CONABIO, SEDUMA, Mexico. 